\title{
The Main Activities of Community-Based Maternal Empowerment for Stunting Recovery
}

\author{
Muksin Muksin ${ }^{1 *}$, Dhyani Ayu Perwiraningrum², Dahlia Indah Amareta ${ }^{3}$, Dwi \\ Purwoko $^{4}$ \\ ${ }^{1}$ Agribusiness Departement, Politeknik Negeri Jember, Indonesia \\ ${ }^{2,3}$ Health Department, Politeknik Negeri Jember, Indonesia \\ ${ }^{4}$ The Indonesian Institute of Science, LIPI, Jakarta, Indonesia \\ *Corresponding author.Email: muksin@polije.ac.id
}

\begin{abstract}
Family efforts in the recovery of stunting in Jember are increasingly under pressure during the Covid19 pandemic. Knowledge in food, personal hygiene, education, and the role of local institutions contribute to the family, especially the empowerment of mothers with stunting children. Their empowerment will have an impact on the ability of childcare in dealing with stunting. Stunting recovery efforts need to be accompanied by sensitive nutritional interventions leading to the mothers and strengthening coping mechanisms. Poverty and deprivation are some of the reasons why mothers feel low-quality food is cheap. On the other hand, there are potential local foods in Jember that have not been utilized. The purpose of this study was to determine several main activities that could be used as a framework for community-based maternal empowerment activities in stunting recovery. This research method used quantitative and qualitative approaches. Description of local food sources and their processing, demographics, and maternal behavior, was carried out through focus group discussion activities involving key stakeholders. The findings of this study were necessary efforts to strengthen the management of stunting handling and promotion of stunting recovery through local information media. The implication of such activities was the need to improve institutional coordination and strengthen the participation of all components of rural communities.
\end{abstract}

Keywords: Main Activities, Maternal Empowerment, Local Food, Stunting.

\section{INTRODUCTION}

Jember is one of the districts with a fairly high stunting rate. Development efforts have been made to improve the ability to overcome stunting in Jember. Handling stunting becomes not easy with various obstacles. One of them is the pandemic period that increases the heavy burden of every family in overcoming economic problems, not least families with stunting children. Pandemics that cause productive economic activities to not run normally have increased the level of difficulty of families in overcoming their food needs. The family must rigidly distribute food rations to family members. This condition has the opportunity for mothers to lack proper food in terms of the amount of nutritional quality [1].

Stunting eradication programs have been implemented nationwide. The program has been run-up to the village level. However, pandemic conditions have led to rationalization and budget reallocation for pandemic management activities. The main focus of food is rice. Rice is still considered a staple food and nutrition provider [2]. This actual problem is also coupled with the development of stunting that is still not optimal. Service activities are not optimal because of the ability of service cadres. In addition, there is a condition of domicile of the target audience of service, in this case, families or mothers with stunting children who are not exposed to service institutions.

As the main target group, stunting children need facilitation and empowerment efforts [3] [4], both in terms of environmental intervention and facilitation of food needs. Food needs are also related to the ability of the mother, as well as the availability of adequate nutrition in terms of quantity and quality. Food fulfillment becomes very vital and urgency to prevent 
stunting is one of the problems related to the availability of proper nutritional intake so that stunting children can meet their health and height eligibility [1] [5].

In the development of stunting, the role of a mother becomes very central. Subjects must be empowered because mothers carried out the whole process of facilitation of child development. Included in this is how the decision-making process and creativity of food processing can be done to provide proper nutrition amid the pressures of the socio-economic environment. Decision-making is also related to the pattern of roles and spaces available to mothers for decision-makers in childcare related to the father as the head of the family. This condition is not easy to resolve considering that the constellation of patriarchal relationships has not provided enough space for women in decision-making. The ability of the mother as one of the "providers" of food will be more difficult with high financial pressures. These conditions can have consequences for inappropriate food choices due to mere consideration of food prices [1] [6].

The role of women is institutionalized social consequences. Local institutions that are expected to play a role, have not been optimal as expected. Considering these conditions, this study aimed to determine the activities that were interrelated in maternal empowerment activities, and analyze the main activities that could be done so that the empowerment of mothers with stunting children could be carried out effectively.

\section{METHOD}

Mothers in families with stunting children have a strategic role in handling and eradicating stunting children. The mother's overall ability will make a significant contribution in facilitating the growth and development of children, especially children with stunting problems. Women as mothers in the house do not live in a vacuum. The entire activity has dimensions related to the family dimension, institutional and social environment in the residence. Thus the activities in empowering the mother must be designed with all environmental variables in mind. This study deployed quantitative and qualitative approaches. The study was conducted in the highest districts of stunting cases which include: Silo, Sumbersari, Wuluhan, and Panti, Jember district. Descriptive quantitative methods, survey techniques with unstructured interviews were carried out to obtain maternal characteristics and behavior in stunting recovery. Focus group discussions were conducted to obtain issue sharpening [7] [8]. Maternal respondents were determined purposively based on stunting children at each selected location. Based on literature studies and interviews, there were interrelated activities in maternal empowerment activities with stunting children. Furthermore, evaluation and measurement of comparisons between activities that needed to be done in empowerment were carried out with experts and key stakeholders using intelligence judgment including related agencies, health experts, local institutions, village facilitators, and academicians. The experts' assessment results set the main activity in the empowerment of mothers with stunting children. The main activity was a variable that was expected to have a significant impact on maternal empowerment.

\section{RESULTS AND DISCUSSION}

\subsection{Characteristics of a Family with Stunted Children}

Families with stunted children have characteristics with relatively similar handling needs. Several villages where the research was conducted were villages where migrant workers (TKW) lived. It was also found that they were faster to obtain ID cards and visas to become TKW. Early marriage was one of the factors that contributed to the ability of childcare. In addition, the management of food availability was not adequate. On the other hand, integrated agricultural management is very potential and proven to increase food availability [9]. These conditions have not been properly utilized.

People in the subdistrict who were observed did not have any interest in seeking information about cases of malnutrition experienced by their families. Some showed less concern for their children's identification and development data.

There were still myths growing up in some places related to the prohibition of checking pregnancy before the age of 3 months because it could cause the fetus to disappear. The pregnant mother should not be immunized because it could cause pain. Stunted toddlers' mothers preferred to buy traveling snacks to give to their children so as not to fuss rather than cooking by themselves by processing more nutritious food that was easily obtained in the home environment such as vegetables, fruits, eggs, and livestock meat.

Society did not have the ability and power to demand services that were not bureaucratic, so there was apathy. Cadres did not have expertise in implementing the role especially in determining problems and solutions that could be a long-term program for villages to combat stunting. It resulted in stunting countermeasures in the village being ineffective, and the village funds had not been optimized in handling stunting.

One of the stunting children was Azka. Azka was the second child of Bapak Nidin and Ibu Ana. Both only finished their education from elementary school. They lived in Plinggian, Antirogo, Sumbersari Subdistrict. This village is an area with the majority of Madura 
tribal population. Bapak Nidin works as a construction worker (handyman server) and Ibu Ana is a housewife. The family occupy a house with an area of about $40 \mathrm{~m} 2$ with a small plot of a yard that was not well managed. Like most homes in the area, ventilation and lighting on the inside of the house were not good. The source of water used was well water.

Ibu Ana, when pregnant with Azka at the age of 28 years, was a pregnant woman at high risk because of her swollen legs. Azka's birth gap with her older brother was 10 years. Azka was born normal (weight of 2800 grams), had complete immunization, and attended to Posyandu until the age of 2 years routinely. However, since the pandemic, Posyandu service stopped so they were not able to monitor his growth. Ibu Ana said her son was small but healthy. Azka's appetite was good, but sometimes he was reluctant to eat. At the beginning of the birth, Azka also consumed infant formula, but only 3 boxes. He did not consume infant formula after being breastfed until he was 3 months old. After then, he was given instant baby porridge as well as rice porridge made by themselves.

Posyandu is 200 meters from his home and can be reached on foot. Ibu Ana claimed there has never been any program other than $\mathrm{bb} / \mathrm{TB}$ weighing or about childcare. Ibu Ana hoped someone taught material such as a skills class for mothers with toddlers. The source of health information that was widely accessed by $I b u$ Ana was social media, such as Facebook and Whatsapp (WA).

\subsection{Relatedness of Activities in Handling Stunting}

The development of a development policy cannot be separated from the analysis of a condition and proper identification of the problems or constraints around the development needs. The policy is further translated into relevant activities to achieve development goals.

In efforts to develop mother empowerment with stunting children, clear goals and what are the main relevant activities can be designed to arrange activities that have an impact on empowerment. Serious efforts to understand the main goals and activities in the development of maternal empowerment through local food development including stunting are a priority to be implemented.

Based on literature reviews, discussions with the public through Focus Group Discussion (FGD), and interviews with experts can outline some related activities and influence the development of communitybased maternal empowerment for stunting recovery. Activities to design to empower mothers with stunting children are: a) Organizational determination and leading sector handling stunting, b) Implementation Design, monitoring and evaluation of the development of maternal and child health and welfare empowerment, c) Design implementation of ICT-based promotion and other methods, d) Extension of stunting handling and maternal health, e) Extension of good food management practices, f) Extension and training of skills to manage food based on local materials, g) Facilitation of related institutional cooperation in the development of maternal empowerment, h) Facilitation of strengthening cooperation of local food management actors, i) Design of nutritious local food products, j) Design of management and standard operational procedures (SOP) for each stage of local food management, k) Development of mutual trust and cooperation between actors handling maternal and child health, 1) Development of production centers for rural mothers' businesses, m) Strengthening the cooperation of related institutions for the availability of human resources health facilitators in the countryside, n) Strengthening joint cross-sectoral commitment in the recovery of stunting children, n) Social marketing development (social marketing) for stunting recovery, o) Strengthening local information media for advocacy and nutritional literacy, and p) Strengthening local information media for nutritious food management and stunting recovery.

\subsection{Key Activities in Empowering Mothers with Stunted Children}

There are seventeen (17) activities that have a connection to discuss maternal empowerment activities. Furthermore, based on the justification of experts, and the results of calculations based on geometric averages obtained, the main activities had relatedness and relevance to the development of mother and community empowerment shown in Table 1.

Table 1 Activity elements for mother empowerment program activities with stunting children

\begin{tabular}{lll}
\hline $\mathrm{N}$ & Sub elements & $\begin{array}{l}\text { Geo- } \\
\text { mean }\end{array}$ \\
\hline 1 & $\begin{array}{l}\text { Organization determination and leading sector } \\
\text { handling stunting }\end{array}$ & 4.00 \\
2 & $\begin{array}{l}\text { Implementation design, monitoring, and } \\
\text { evaluation of the development of health } \\
\text { empowerment and welfare of mothers and } \\
\text { children }\end{array}$ & 4.00 \\
3 & $\begin{array}{l}\text { Design Implementation of ICT-based } \\
\text { promotions and other methods }\end{array}$ & 3.46 \\
4 & $\begin{array}{l}\text { Extension of stunting and maternal health } \\
5\end{array}$ & $\begin{array}{l}\text { Counseling of good food management } \\
\text { practices }\end{array}$ \\
6 & $\begin{array}{l}\text { Counseling and training skills managing local } \\
\text { ingredient-based food }\end{array}$ & 3.00 \\
7 & $\begin{array}{l}\text { Facilitation of related institutional cooperation } \\
\text { in the development of maternal empowerment }\end{array}$ & 3.46 \\
8 & $\begin{array}{l}\text { Facilitation of strengthening cooperation of } \\
\text { local food management actors }\end{array}$ & 3.46 \\
9 & $\begin{array}{l}\text { Design of nutritious local food products } \\
\text { Desion }\end{array}$ & 3.46
\end{tabular}


10 Design of management and standard operational procedures (SOPs) for each stage of local food management

11 Development of mutual trust and cooperation between actors handling maternal and child health

12 Development of production centers for mothers' businesses in the countryside

13 Strengthening the cooperation of related institutions for the availability of human resources health facilitators in the countryside

14 Strengthening cross-sector joint commitment in stunting child recovery

15 The development of social marketing for stunting recovery

16 Strengthening local information media for advocacy and nutrition literacy

17 Strengthening local information media for nutritious food management and stunting recovery

There were 5 activities that experts assessed to have the highest contribution in empowering mothers based on geomean values. The activities were the establishment of organizations and leading sectors for stunting handling, implementation design, monitoring and evaluation of the development of maternal and child health and welfare empowerment, social marketing development (social marketing) for stunting recovery, strengthening local information media for advocacy and nutritional literacy, and strengthening local information media for nutritious food management and stunting recovery.

The five activities could be categorized into three categories, namely, 1) activities related to strengthening the structure and clear institutional authority, 2) the strengthening of programs clearly and accountability, and 3) activities related to marketing or promotion of stunting recovery behavior and food handling.

The first category was activities related to the strengthening of a clear institutional structure. The activity in question was the determination of organization and leading sector handling stunting. The authority and determination of institutions that were the coordination node for handling maternal empowerment must be clear and understand the implementation to the lowest or rural levels.

The second category was the strengthening of the program clearly and accountably. Included in the activities in this category were the design of the implementation, monitoring, and evaluation of the development of maternal and child health and welfare empowerment. The determination of the mother empowerment program in such a way must go through planning based on valid data, implemented with specific, measurable, achievable, relevant, and time- bound measures. In addition, monitoring and evaluation were needed with the size and indicators that were set.

The third category was related activities in the context of marketing stunting recovery behavior and food handling. Categories in this activity were the development of social marketing (social marketing) for stunting recovery, strengthening local information media for advocacy and nutritional literacy, and strengthening local information media for nutritious food management and stunting recovery. Counseling was required based on existing problems [10]. Especially related to local food sources, it was necessary to increase understanding for a substitution or alternative foods such as corn. Corn has fairly good content and provides enough nutritional intake [11]. However, it was not well utilized. Behavior change requires systematic effort through counseling by utilizing media and methods that facilitate the target audience.

Empowering mothers with stunted children requires clarity of their institutions and authority. Program planning, implementation, and evaluation are primarily in behavior change through systematic counseling will provide ease of measurement of achievements and priority management over time. The implementation of this activity simultaneously will contribute to the empowerment of mothers with community-based stunting children.

\section{CONCLUSION}

Three fundamental things have significant value in empowering mothers with stunting children that can be concluded in this study, namely, the category of activities related to the clarity of institutional structures and coordination that handle stunting, the need for clear planning design, implementation, and monitoring, as well as social awareness activities that facilitate behavioral changes in anticipating and dealing with stunting. Aspects of HR development, strengthening structure, and management of stunting development become very significant to empower mothers with stunting children.

\section{AUTHORS' CONTRIBUTIONS}


This research contributed importantly in terms of identifying activities related and interconnected in maternal empowerment activities with communitybased stunting children. The activities formulated met the dimensions that include: a) aspects of human resources, namely mothers with stunting children as target audiences, families, facilitators, and empowerment, b) institutions related to the components of their needs and policies that must be done, and c) the development of food potential as a real effort in providing and fulfilling nutritious, quality and accessible families with stunting children.

\section{ACKNOWLEDGMENTS}

The authors thank Politeknik Negeri Jember for funding the research. The research was wellimplemented due to the contribution of some parties such as the Health Office, Community and Village Empowerment Office, Jember Regency Agriculture Office, Health Center officers, village organizers, and facilitators.

\section{REFERENCES}

[1] D. A. Perwiraningrum, "Need Assessment of Stunted Children During Pandemic Covid-19 to Develop Nutrition Intervention Program in Jember District , East Java , Indonesia," vol. 514, no. Icoship 2020, pp. 160-164, 2021.

[2] H. Saliem, S. Susilowati, A. Ariningsih, A. Agustin, and Muksin, "Supporting organic rice exports: the success story of West Java organic rice exports Supporting organic rice exports: the success story of West Java organic rice exports," pp. $\quad 0-8, \quad 2021, \quad$ doi: $\quad 10.1088 / 1755-$ 1315/672/1/012095.

[3] Muksin, R. Hari, K. Tanti, and I. Titik, "The main problems of na-oogst tobacco agribusiness in Jember," IOP Conf. Ser. Earth Environ. Sci., vol. 207, 2018, doi: 10.1088/1755-1315/207/1/012012.

[4] R. Kumar and S. Lakhtakia, "Women' Empowerment and Child Stunting in India: An Investigation," J. Popul. Soc. Stud., vol. 29, pp. 47-66, 2020, doi: 10.25133/JPSSv292021.004.

[5] C. Desmond and D. Casale, "Catch-up growth in stunted children: Definitions and predictors," PLoS One, 2017, doi: https://doi.org/10.1371/journal.pone.0189135.

[6] A. Khomsan, H. Riyadi, and S. A. Marliyati, "Ketahanan Pangan dan Gizi serta Mekanisme Bertahan pada Masyarakat Tradisional Suku Ciptagelar di Jawa Barat (Food Security and Nutrition and Coping Mechanism in Ciptagelar Traditional Community in West Java )," vol. 18, no. 3, pp. 186-193, 2013.
[7] S. G. Purnama, Panduan Focus Group Discussion ( FGD ) dan Penerapannya Program Studi Ilmu Kesehatan Masyarakat Universitas Udayana Kata Pengantar. .

[8] A. Paramita, "TEKNIK FOCUS GROUP DISCUSSION DALAM PENELITIAN KUALITATIF (Focus Group Discussion Tehnique in Qualitative Research )," pp. 117-127.

[9] Muksin, Rizal, and R. Iskandar, "Analysis of the Sustainable Status of Post Disaster Crop Production in Sigi Regency, Central Sulawesi Province," IOP Conf. Ser. Earth Environ. Sci., vol. 672 , no. 1, 2021, doi: 10.1088/17551315/672/1/012031.

[10] U. Maman et al., "Formulating extension model to encourage staple food diversification: A solution to food crisis potential," Univers. J. Agric. Res., vol. 9, no. 4, pp. 138-148, 2021, doi: 10.13189/UJAR.2021.090405.

[11] S. Susilowati, E. Ariningsih, H. Saliem, E. Roosganda, C. Adawiyah, and Muksin, "Opportunities and challenges to increase corn export from Gorontalo province of Indonesia," pp. 0-9, 2021, doi: 10.1088/1755-1315/672/1/012027. 